\title{
Nitrate and Salt Water Contamination Associated with the Transition of an Agrarian Basin into an Irrigated Area
}

\author{
Raphael Abrahao ${ }^{1 *}$, Jesús Causapé ${ }^{2}$, David Moreno-Mateos ${ }^{3}$, Francisco Comín ${ }^{4}$
}

\begin{abstract}
The introduction of irrigation to agrarian areas involves several environmental changes that can be aggravated by physical and agronomic factors. The aim of this study is to analyze the spatiotemporal dynamics of the environmental impact on water resources that result from the transition of an agrarian basin into an irrigated area. During five hydrological years, a spatiotemporal comparison was carried out on the quantity and quality of drainage from the four zones in which the study area was subdivided. Introduction of irrigation activities incorporated flows that lowered salinity and increased nitrate concentration in the basin. The zones/years with most irrigation showed the greatest exports of salts and nitrates, with temporal variations related to rainfall patterns and spatial variations related to soil salinity and nitrogenous fertilization. The agro-environmental impacts of the gradual introduction of irrigation into a previously non-irrigated area were congruent to that of established irrigation areas with similar characteristics. Water Environ. Res., 84 (2012).
\end{abstract}

Keywerds: downstream impacts, irrigation, nitrate, salts, water quality. doi:

\section{INTRODUCTION}

Despite productive and economic benefits, the implementation of agricultural irrigation involves environmental changes in both the transformed area and in downstream regions. The main impacts derived from irrigation are usually nitrate contamination (Charbonneau and Kondolf, 1993; Klocke et al., 1999; Ribbe et al., 2008), salinization of soils and waters (Lemly et al., 1993; Tanji and Kielen, 2002), and changes in the natural regimens of water systems (Baldock et al., 2000, Cai et al., 2003). These impacts can be aggravated by physical factors (climate and geology) and agronomic management (irrigation and fertilization management). For instance, the natural salinity of the soil can contribute significantly to the export of salts from the

\footnotetext{
* Corresponding author: rabrahao@mirarco.org, Tel.: +1 705675 $1151 \times 5107$, Fax: +1 7056754838

1 MIRARCO - Mining Innovation, Rehabilitation and Applied Research Corporation, Laurentian University, 935 Ramsey Lake Road, Sudbury, ON, P3E 2C6, Canada.

2 Instituto Geológico y Minero de España. C/ Manuel Lasala 44, $9^{\circ} \mathrm{B}$, 50006, Zaragoza, Spain.

${ }^{3}$ Jasper Ridge Biological Preserve, Stanford University, 4001 Sandhill Road, Woodside, CA 94062, United States.

${ }^{4}$ Instituto Pirenaico de Ecología-CSIC \& Parque Científico Aula Dei. Av. Montañana 1005, 50192, Zaragoza, Spain.
}

irrigated land (Causapé, 2008). Heavy rainfall events, on the other hand, can cause lateral and vertical mobility of such salts in the soil, which can cause a considerable increase in the exported masses (Thayalakumaran et al., 2007).

In many cases, the impacts affect the agricultural sector itself. By the 1940s, an important area of the San Joaquin Valley (United States) was abandoned because of salt buildup and poor drainage (Lemly et al., 1993).

Regarding agronomic factors, García-Garizábal et al. (2009) verified that adequate management of irrigation water can significantly reduce the export of salts and nitrates from an agricultural basin. Gheysari et al. (2009) indicated that it is possible to control the levels of nitrate leaching from the root zone through adequate management of irrigation and fertilization. Furthermore, Moreno et al. (1996) showed that a reduction in nitrogen fertilization can decrease nitrate-leaching levels without causing a decline in production-and thus, reach equilibrium between high productions and acceptable environmental impacts.

Water quality monitoring and quantification of the export of pollutants from an agricultural basin allow for the diagnosis of agro-environmental problems caused by irrigation, and also for a better representation of the impacts on the water resources downstream (European Environment Agency, 1999; U.S. Environmental Protection Agency, 2002; Cavero et al., 2003; Lovett et al., 2007; Gheysari et al., 2009). However, this type of study, traditionally accomplished in consolidated irrigation lands, is not carried out as a preventive measure against agro-environmental impacts caused by the transition into an irrigated land. All stages (before, during, and after) of the transition should be compared, thereby quantifying the true agro-environmental impacts involved and analyzing spatiotemporal dynamics for the establishment of an adequate environmental monitoring plan.

The objective of this study is to investigate the dynamics of the impacts (mainly quantity and quality of irrigation return flows) caused by the transformation of an agricultural basin (from unirrigated to irrigated land). Four different scenarios of implementation of irrigation, nitrogen fertilization, soil salinity, and climatic differences were considered throughout five consecutive years in a semiarid Mediterranean agrarian basin.

\section{DESCRIPTION OF THE STUDY AREA}

The study area corresponds to the hydrological basin of the Lerma gully (752 ha), located on the left margin of the medium Ebro river valley in Northeast Spain (Figure 1). Lerma basin is 
Location of Lerma basin
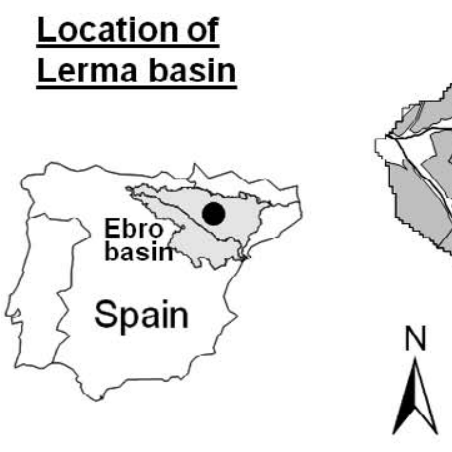

$0 \quad 500 \quad 1000$ meters

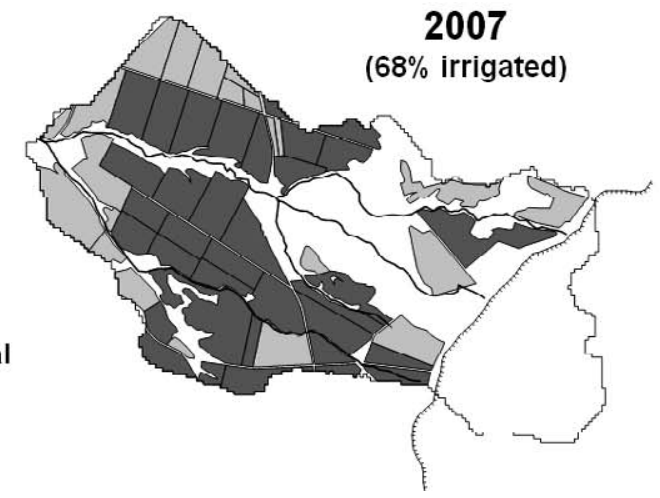

(unirrigated)
2004 to 2005

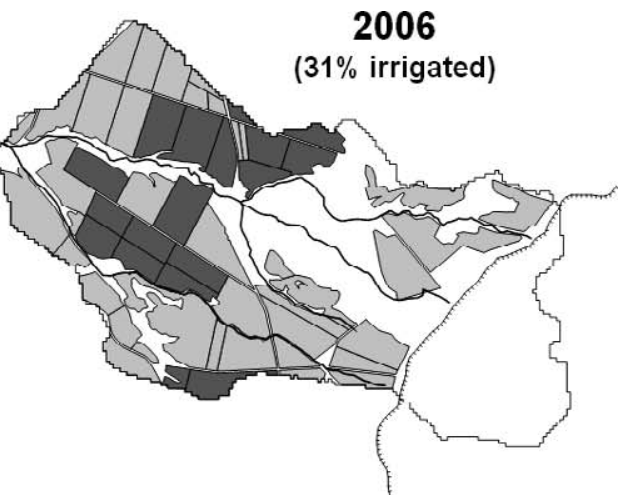

2008

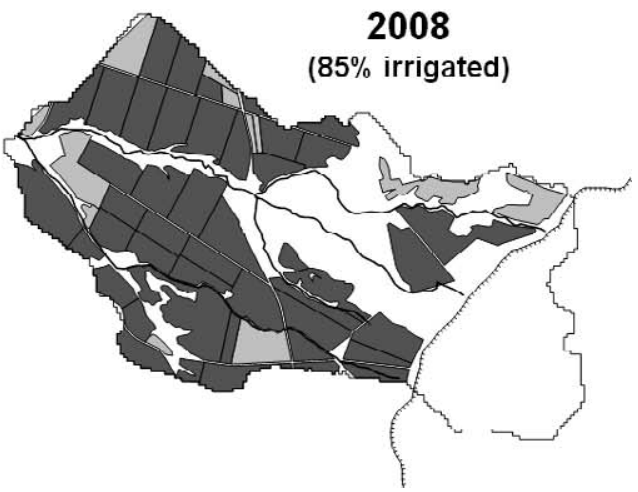

Figure 1-Location of Lerma basin in the Ebro river basin (Spain) and dynamics of its transformation into irrigated area.

constituted of quaternary glacis composed of gravel with loamy matrix, in which the maximum thickness does not exceed $10 \mathrm{~m}$. Tertiary materials (limestone, clay, and gypsum) can be found surfacing below the valley (carved by the natural drainage network), and are considered to be the main source of salts in the study area (Causapé et al., 2004). Introduction of irrigation was planned mainly for the glacis areas of the basin, with soils presenting low apparent electrical conductivity $\left(\mathrm{ECa}_{\text {average }}\right)(0.16$ $\mathrm{dS} / \mathrm{m}$ ); conversely, the soils developed in the valleys, where tertiary substratum emerge, presented an $\mathrm{ECa}_{\text {average }}$ three times higher $(0.44 \mathrm{dS} / \mathrm{m})$.

The climate of the region is dry, with hot summers and cold winters. Average annual precipitation in the basin during the studied years was $408 \mathrm{~mm}$ (SIAR, 2008), whereas the average reference evapotranspiration $\left(\mathrm{ET}_{0}\right)$, calculated via PenmanMonteith equation (Allen et al., 1998), was three times higher (1261 mm/yr). Considering the climate of the region, irrigation becomes indispensable for the development of crops with high water requirements (for example, maize and tomatoes), besides being fundamental for the achievement of higher productivity in crops with lower water demands (for example, winter cereals).

The study began in the hydrological year of 2004, before irrigation (sprinkler and drip) was implemented. The transition project delimited 405 ha of the Lerma basin to be irrigated. In 2006 , irrigation began in $31 \%$ of the delimited area, gradually increasing proportions in 2007 (68\%) and 2008 (85\%), the final year covered by this study (Figure 1). The basin was originally cultivated with winter cereals (wheat and barley) under unirrigated conditions; cultivation stopped in 2003 for the beginning of the transition to irrigated land. Maize was the most widespread crop in the early years of irrigation (2006 to 2008), occupying $57 \%$ of the irrigable area. Other important crops were winter cereals and tomatoes (23\% and $11 \%$, respectively). Sprinkler irrigation was established in $86 \%$ of the area, whereas drip irrigation was present in the remaining $14 \%$. The salinity of the irrigation water $(\mathrm{EC}<0.4 \mathrm{dS} / \mathrm{m})$ does not pose limitations on the cultivated crops, and the nitrogenous fertilizers applied were mainly NPK compound fertilizers (mostly 8-15-15 and 15$15-15)$, urea (46\% nitrogen), and liquid fertilizers applied with irrigation (32\% nitrogen).

\section{METHODOLOGY}

Zoning of Lerma Basin. Four locations of Lerma basin were selected $\left(\mathrm{P}_{\mathrm{A}}, \mathrm{P}_{\mathrm{B}}, \mathrm{P}_{\mathrm{C}}\right.$, and $\mathrm{P}_{\mathrm{D}}$; Figure 2$)$ in such a way that, based on the Digital Terrain Model $25 \times 25$ (MIMAM, 2003), Lerma basin was divided into four sub-basins $(A, A+B, A+B+C$, and $D)$. After separating the overlapping areas of the sub-basins, four separate zones (A, B, C, and D) were obtained, with comparable sizes and different geology and land use characteristics (Table 1).

Salinity and Nitrate Concentration in Water. The four selected locations in Lerma basin were sampled monthly between October 2003 and September 2008 (hydrological years 2004 to 2008). Water samples were transported to the laboratory, where the electrical conductivity of water corrected to $25^{\circ} \mathrm{C}$ (EC) and nitrate concentration $\left(\left[\mathrm{NO}_{3}{ }^{-}\right]\right)$were determined. To this end, a conductivity meter and a nitrate autoanalyzer were utilized, and a total of 240 water samples were collected and analyzed for this study.

Export of Agrarian Contaminants. The spatiotemporal dynamics of the contaminants (salts and nitrates) exported via

Water Environment Research, Volume 84-Copyright (c) 2012 Water Environment Federation Uncorrected Page Proofs 


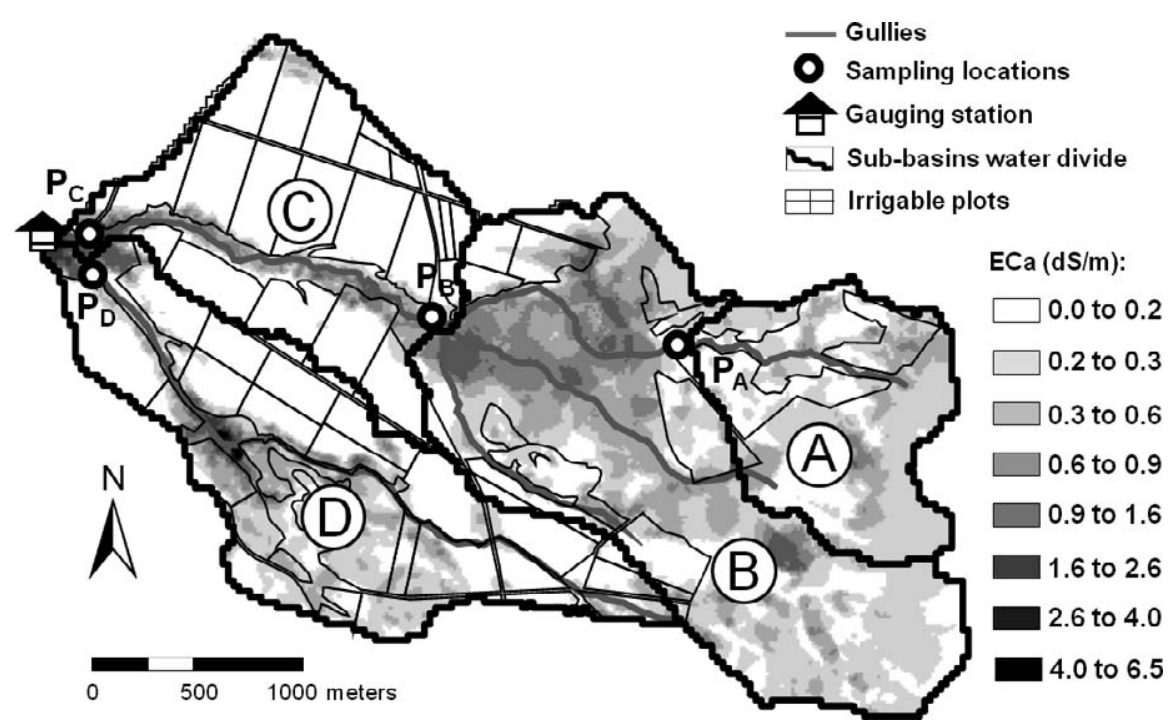

Figure 2-Sampling locations $\left(P_{A}, P_{B}, P_{C}, P_{D}\right)$, Lerma basin zoning $(A, B, C, D)$ from the hydrological sub-basins of the sampled locations, and apparent electrical conductivity of soils (ECa).

drainage were analyzed regarding climatic, geological, and agronomic factors. The drainage flow of the entire Lerma basin was monitored by a gauging station built in August 2005 (Figure 2). The flume has a rectangular section for regular flows inferior to $0.5 \mathrm{~m}$ in height and a trapezoidal section for extraordinarily higher flows. The installation of an electronic limnigraph allowed for recording water height (h) measurements every 15 minutes, which were then converted into flow (Q) measurements. Conversion was accomplished through the output curves of the flume, obtained with WinFlume (Wahl, 2000), depending on the flow ranges:

$$
\begin{aligned}
& \mathrm{Q}\left[\mathrm{m}^{3} / \mathrm{s}\right]=1.73 \times(\mathrm{h}[\mathrm{m}]+0.00347)^{1.624} \quad \text { for } \mathrm{h} \leq 0.5 \mathrm{~m} \quad 1 \\
& \mathrm{Q}\left[\mathrm{m}^{3} / \mathrm{s}\right]=10.28 \times(\mathrm{h}[\mathrm{m}]+0.01125)^{1.725} \quad \text { for } \mathrm{h} \leq 0.5 \mathrm{~m} \quad 2
\end{aligned}
$$

The flow drained in the period before the installation of the gauging station was estimated using the runoff coefficient (0.087) obtained in the basin through the rainfall-flow relationship in the period before the irrigation started (October 1, 2005 to March 31, 2006). Each sampling location did not have its own gauging station; therefore, the flow associated with each subbasin was estimated by dividing the total flow measured at the

Table 1-Zone areas, percentages of irrigable areas, proportions transformed to irrigated areas in 2008, average irrigation doses and nitrogen fertilizations (NF), and average ECa of the soils of each zone.

\begin{tabular}{lcccc}
\hline Zone & $\boldsymbol{A}$ & $\boldsymbol{B}$ & $\boldsymbol{C}$ & $\boldsymbol{D}$ \\
\hline Area (ha) & 112 & 269 & 168 & 203 \\
Irrigable area (\%) & 30 & 23 & 82 & 84 \\
Transformed in 2008 (\%) & 14 & 23 & 73 & 72 \\
Irrigation rate (mm/yr) & 29 & 42 & 222 & 174 \\
NF (kg N/ha.yr) & 5 & 25 & 87 & 99 \\
ECa (dS/m) & 0.24 & 0.35 & 0.17 & 0.27 \\
\hline
\end{tabular}

flume in function of the input of water to each sub-basin, because of precipitation and irrigation.

In 17 water samples, which composed the range of variation of EC in Lerma gully, the concentration of bicarbonate $\left(\left[\mathrm{HCO}_{3}{ }^{-}\right]\right)$and dry residue (DR) were determined to obtain the total dissolved solids (TDS):

$$
\begin{aligned}
\operatorname{TDS}(\mathrm{mg} / \mathrm{L})= & \mathrm{DR}(\mathrm{mg} / \mathrm{L})+1 / 2 \mathrm{HCO}_{3} \\
& -(\mathrm{mg} / \mathrm{L}) ;(\text { Custodio and Llamas, } 1983) \quad 3
\end{aligned}
$$

Through a regression, the equation allowing for the conversion of EC into TDS in each collected sample was obtained:

$$
\begin{aligned}
\mathrm{TDS}(\mathrm{mg} / \mathrm{L}) & =712.22 \times \mathrm{EC}(\mathrm{dS} / \mathrm{m})-104.83 ; \mathrm{n}=17 ; \mathrm{R}^{2} \\
& =0.99 ; \mathrm{p}<0.01
\end{aligned}
$$

Exports of salts and nitrates in each sub-basin were quantified by multiplying the concentrations (TDS and $\left[\mathrm{NO}_{3}{ }^{-}\right]$) obtained at each sampling location $\left(\mathrm{P}_{\mathrm{A}}, \mathrm{P}_{\mathrm{B}}, \mathrm{P}_{\mathrm{C}}\right.$, and $\left.\mathrm{P}_{\mathrm{D}}\right)$ by the corresponding monthly drainage volume. The masses exported in each zone were determined through the difference between overlapping sub-basins.

Statistical Analysis. A comparison of water quality among both sampling locations and study years (unirrigated years versus irrigated years, at each location) was performed through Kruskal and Wallis (1952) and Mann and Whitney (1947) nonparametric methods, for a probability of a less-than $5 \%$ error (p $<0.05)$

A multivariate cluster analysis (Hair et al., 1998) was carried out to analyze more profoundly the spatiotemporal dynamics of flow and export of salts and nitrates via drainage. In addition to flow and export of salts and nitrates, variables such as precipitation, irrigation, soil salinity, and nitrogen fertilization for each study year at each zone were used, thereby obtaining data from 20 year-zone combinations (five years in four zones).

Annual precipitation data was obtained by interpolation using the inverse square distance (Isaaks and Srivastava, 1989) of daily data recorded at two agroclimatic stations present in the area (SIAR, 2008). The amounts of irrigation and fertilizer applied at 

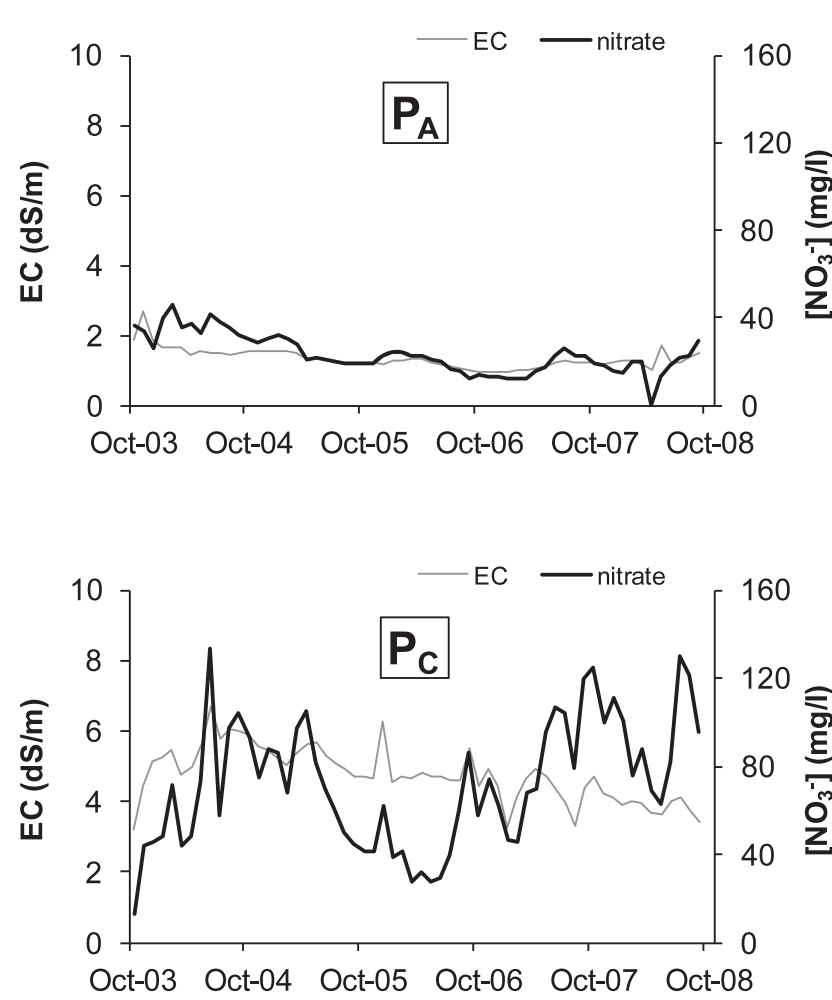
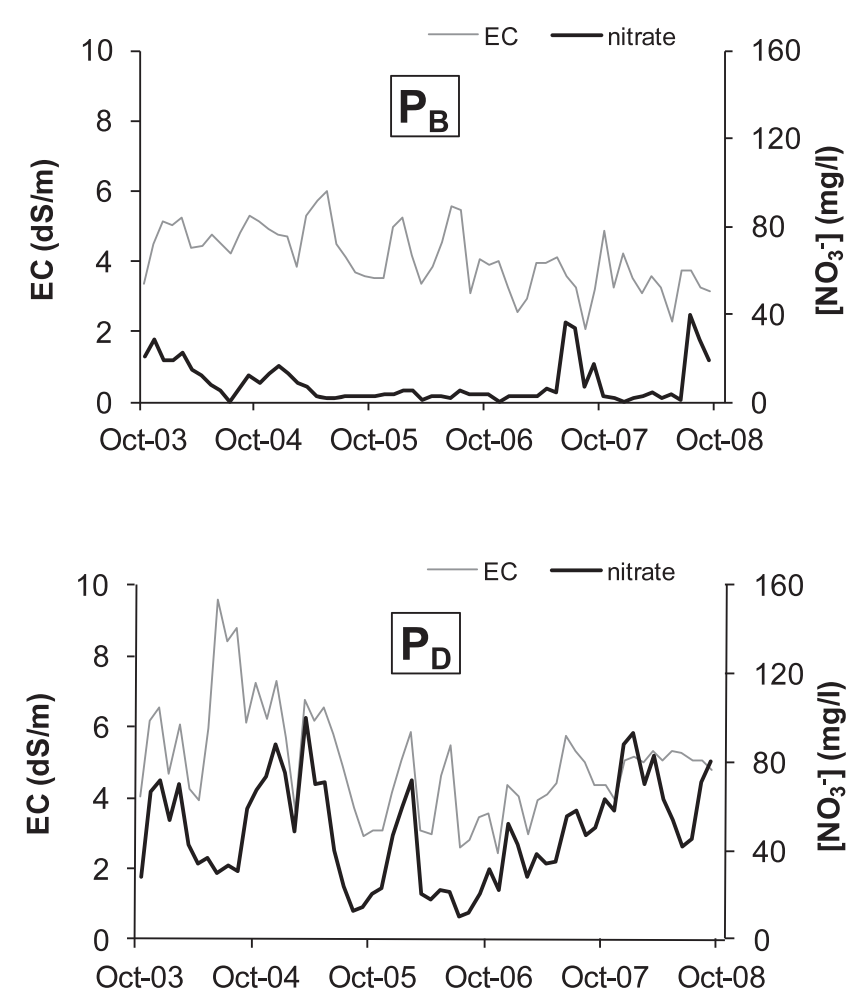

Figure 3-Dynamics of EC and nitrate concentration in sampling locations $P_{A}, P_{B}, P_{C}$, and $P_{D}$.

each year-zone were obtained from the database of the Irrigation District Agency, and from a survey taken from all farmers of the basin. The soil salinity in each area was represented by the average apparent electrical conductivity of soils, obtained from 42275 measurements taken with an electromagnetic sensor (Urdanoz et al., 2008).

Cluster analysis was performed by standardizing the variables and using the Euclidean square distance as a similarity measure. The Ward method was used to obtain hierarchical clustering (Hair et al., 1998). Finally, Pearson correlation analysis was carried out to study in depth the relationships between the variables.

\section{RESULTS AND DISCUSSION}

Characterization of Zones. The four distinct zones (A, B, C, and D) comprise surfaces between 112 ha (zone A) and 269 ha (zone B), with soils presenting $\mathrm{ECa}_{\text {average }}$ between $0.35 \mathrm{dS} / \mathrm{m}$ (zone B) and $0.17 \mathrm{dS} / \mathrm{m}$ (zone $\mathrm{C}$ ). Zones $\mathrm{A}$ and $\mathrm{B}$ were characterized by small irrigable areas $(30 \%$ and $23 \%$ of its surfaces, respectively) in comparison to zones C and D (82\% and $84 \%$, respectively). This way, at the end of the study (2008), zones $\mathrm{A}$ and $\mathrm{B}$ also presented irrigated areas inferior to those of zones $\mathrm{C}$ and $\mathrm{D}$. The irrigation percentage conditioned higher unit volumes of irrigation as well as the application of nitrogenous fertilizer in zones $\mathrm{C}$ and $\mathrm{D}$. With similar irrigation percentages, zone $\mathrm{C}$ was more irrigated because of double cropping practices, and zone $\mathrm{D}$ received a greater input of nitrogen because of its greater area of maize cultivation.

Thus, the different geology and land use characteristicsalong with zone management-were used for the assessment of the spatiotemporal impacts of the implementation of irrigation in the area. The differences and similarities between the four zones can be better observed through Table 1 and Figure 2 .

Salinity and Nitrate Contamination of Water. Average EC of the 240 analyzed samples was $3.8 \mathrm{dS} / \mathrm{m}$, ranging from a minimum of $1.0 \mathrm{dS} / \mathrm{m}$ at location $\mathrm{P}_{\mathrm{A}}$ (September 2006 to April 2007) and a maximum of $9.6 \mathrm{dS} / \mathrm{m}$ at $P_{D}$ (June 2004) (Figure 3 ). The moderate-high salinity of water must be highlighted, as all samples exceeded the limit restriction value for irrigation water $(0.7 \mathrm{dS} / \mathrm{m}$; Ayers and Westcot, 1994). The average value of $\left[\mathrm{NO}_{3}{ }^{-}\right]$was $38 \mathrm{mg} / \mathrm{L}$, with no detection of nitrate in April 2008 (location $\mathrm{P}_{\mathrm{A}}$ ) and a maximum of $133 \mathrm{mg} / \mathrm{L}$ (location $\mathrm{P}_{\mathrm{C}}$ ) in June 2004. The limit set by the European Union ( $50 \mathrm{mg} / \mathrm{L}$; EU, 1998) was exceeded by $29 \%$ of the samples collected. Variability in $\left[\mathrm{NO}_{3}{ }^{-}\right](\mathrm{CV}=82 \%)$ was almost double that of $\mathrm{EC}(\mathrm{CV}=46 \%)$ because, as ascertained in other works (Causapé et al., 2006), the variability associated with hydrological factors is added to the variability associated with the nitrate available for leaching.

Water quality monitoring revealed significant differences (Kruskal-Wallis, $\mathrm{p}<0.05)$ in $\mathrm{EC}$ and $\left[\mathrm{NO}_{3}{ }^{-}\right]$for the four sampling locations. The lowest EC average was found at location $\mathrm{P}_{\mathrm{A}}(1.3 \mathrm{dS} / \mathrm{m})$, which can collect seepage water from the supply canal $(\mathrm{EC}<0.4 \mathrm{dS} / \mathrm{m})$, with drainage waters flowing mainly at glacis levels. The salinity of the water of the gullies increases along the course, as there is a greater contribution of the tertiary to the drained surface, such that location $\mathrm{P}_{\mathrm{B}}$ already exceeds 4 $\mathrm{dS} / \mathrm{m}$ on average. Locations $\mathrm{P}_{\mathrm{C}}(4.7 \mathrm{dS} / \mathrm{m})$ and $\mathrm{P}_{\mathrm{D}}(5.0 \mathrm{dS} / \mathrm{m})$, near the lowest point of the Lerma basin, presented the maximum values of EC.

The lowest nitrate concentration was presented at location $P_{B}$ $(9 \mathrm{mg} / \mathrm{L})$, whose sub-basin (zones $\mathrm{A}$ and B) drains only $25 \%$ of the agrarian area, thus diluting drainage water from $\mathrm{P}_{\mathrm{A}}(23 \mathrm{mg} /$ 


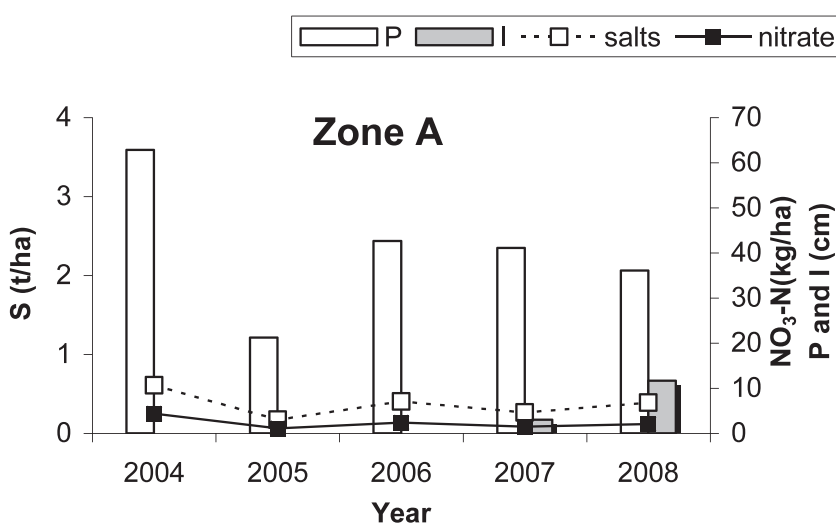

P $\square$ । - - - - salts $\longrightarrow$ nitrate

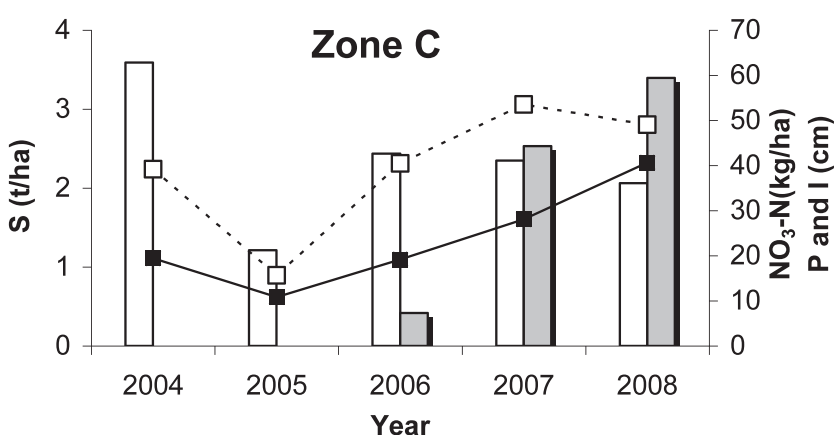

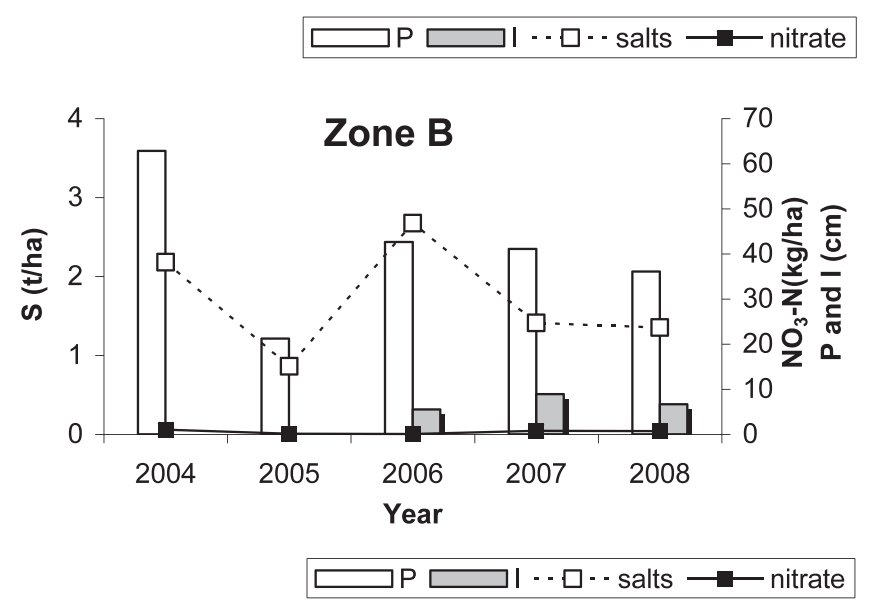

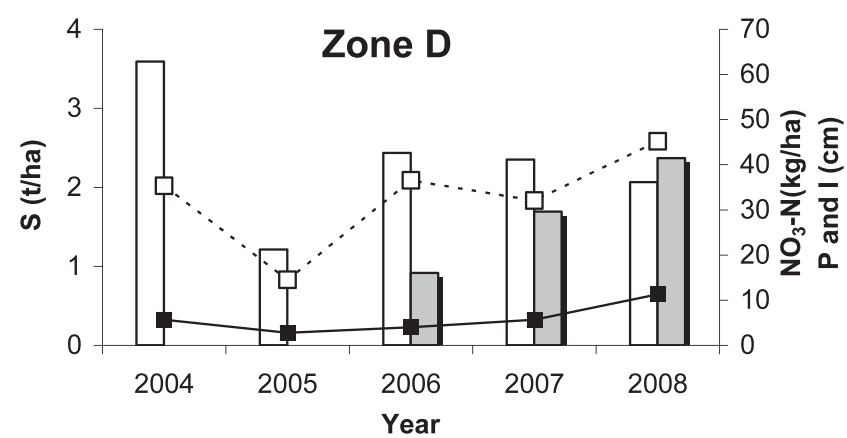

Figure 4-Precipitation (P), irrigation (I), salts (S), and nitrate $\left(\mathrm{NO}_{3}-\mathrm{N}\right)$ exports from zones $\mathrm{A}, \mathrm{B}, \mathrm{C}$, and $\mathrm{D}$ during 2004 to 2008.

L). The contribution of agrarian drainage increased $\left[\mathrm{NO}_{3}{ }^{-}\right]$to 48 $\mathrm{mg} / \mathrm{L}$ in $\mathrm{P}_{\mathrm{D}}$ and to $72 \mathrm{mg} / \mathrm{L}$ in $\mathrm{P}_{\mathrm{C}}$, where $68 \%$ of the samples collected exceeded $50 \mathrm{mg} / \mathrm{L}$.

Temporally, implementation of irrigation has caused a significant decrease (Mann-Whitney, $\mathrm{p}<0.05)$ in water salinity. Average EC of the two unirrigated years (2004 and 2005) was 4.3 $\mathrm{dS} / \mathrm{m}$, whereas in the last three years with irrigation, EC decreased to $3.4 \mathrm{dS} / \mathrm{m}$. However, a slight increase was observed in EC during 2008 (3.4 dS/m) when compared to 2007 (3.2 dS/ $\mathrm{m})$. Inclinations of the $\mathrm{EC} /$ time regressions were negative in all four zones, suggesting that implementation of irrigation has incorporated lower salinity flows to the water flowing through Lerma gully. This situation is consistent with a hypothetical irrigation efficiency of $90 \%$ estimated at other pressurized irrigation systems (Causapé et al., 2006), which would concentrate irrigation water $(\mathrm{EC}<0.4 \mathrm{dS} / \mathrm{m})$ to values approximately $3.5 \mathrm{dS} / \mathrm{m}$, and thus inferior to the "natural" salinity of the drainage in Lerma basin.

The absence of agriculture during the first two study years (2004 to 2005) did not prevent the leaching of nitrate applied in previous years, thus resulting in an average $\left[\mathrm{NO}_{3}{ }^{-}\right]$of $41 \mathrm{mg} / \mathrm{L}$ for the waters of Lerma. With a lower amount of nitrate in the soil, year 2006 presented the minimum value of $\left[\mathrm{NO}_{3}{ }^{-}\right](24 \mathrm{mg} /$ $\mathrm{L})$; since then, with the progressive transition to irrigated land, $\left[\mathrm{NO}_{3}{ }^{-}\right]$has continually increased $(36 \mathrm{mg} / \mathrm{L}$ in $2007,48 \mathrm{mg} / \mathrm{L}$ in 2008).

Locations less influenced by the transition to irrigated land $\left(\mathrm{P}_{\mathrm{A}}\right.$ and $\left.\mathrm{P}_{\mathrm{B}}\right)$ presented a negative inclination for the $\left[\mathrm{NO}_{3}{ }^{-}\right] /$time regression. For locations under more influence $\left(\mathrm{P}_{\mathrm{C}}\right.$ and $\left.\mathrm{P}_{\mathrm{D}}\right)$, inclination was positive and evidenced a gradual increase in nitrate contamination. During irrigation years (2006 to 2008) in $\mathrm{P}_{\mathrm{C}}$ and $\mathrm{P}_{\mathrm{D}}$, a significant increase (Mann-Whitney, $\mathrm{p}<0.05$ ) in $\left[\mathrm{NO}_{3}{ }^{-}\right]$was observed as the irrigated area increased, thus showing the influence of irrigated area on the concentration of salts and nitrates in the Lerma water. Whereas irrigation seems to have decreased water salinity, levels of $\left[\mathrm{NO}_{3}{ }^{-}\right]$increased only in locations receiving drainage from the most transformed zones $\left(\mathrm{P}_{\mathrm{C}}\right.$ and $\left.\mathrm{P}_{\mathrm{D}}\right)$, thus exceeding the already high levels recorded in unirrigated conditions. At $\mathrm{P}_{\mathrm{C}}$, where the greatest $\left[\mathrm{NO}_{3}{ }^{-}\right]$was found, the concentration during the unirrigated period $(71 \mathrm{mg} /$ L) increased to an average of $97 \mathrm{mg} / \mathrm{L}$ in 2008.

Casalí et al. (2008) also found high nitrate concentrations (87 $\mathrm{mg} / \mathrm{L}$ ) in the water drained from an unirrigated basin, located in a zone of higher annual precipitation $(691 \mathrm{~mm})$ and where mainly barley and wheat were cultivated. However, traditional flood irrigation systems obtained a dilution effect in drainage, thus presenting lower nitrate concentrations than those recorded at Lerma (Causapé et al. 2006). Increased irrigation efficiency can lead to a greater concentration of drainage water, as evidenced by data from Gheysari et al. (2009), in which experiments on efficiently sprinkler-irrigated maize plots presented an average $\left[\mathrm{NO}_{3}{ }^{-}\right]$of $138 \mathrm{mg} / \mathrm{L}$.

Cavero et al. (2003) studied two basins with consolidated irrigation developed under conditions similar to those of Lerma basin (that is, similar climate and sprinkler-irrigated maize as the main crop), which presented higher average $\left[\mathrm{NO}_{3}{ }^{-}\right]$(124 and $113 \mathrm{mg} / \mathrm{L}$ ) than those observed in Lerma, thus suggesting that 


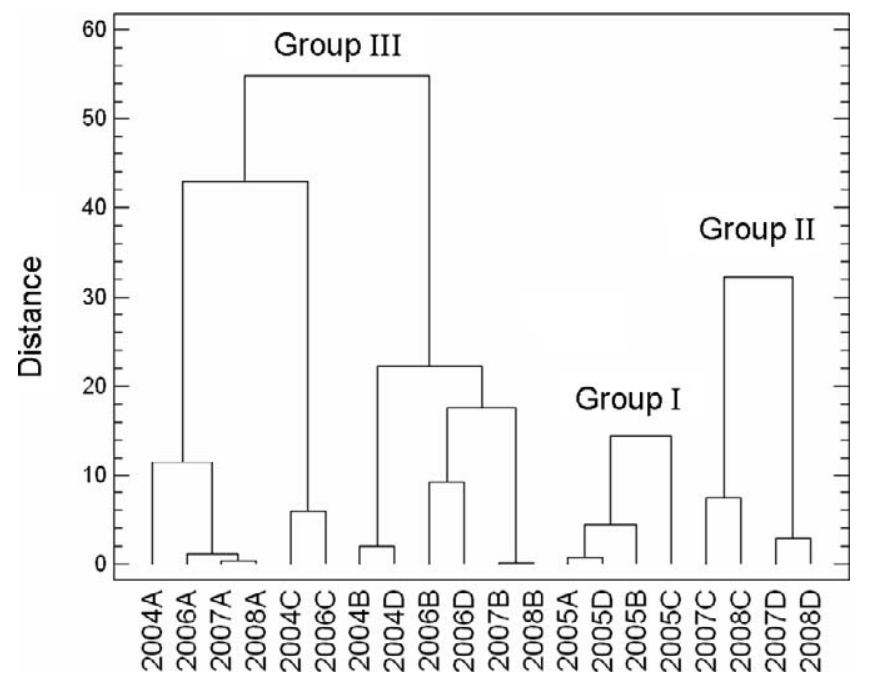

Figure 5-Dendrogram of the cluster analysis that grouped the 20 year-zone combinations into three groups.

nitrate concentrations at Lerma gully could continue to rise slightly in the next years.

Export of Agrarian Contaminants. Zone A presented low export of salts $(0.4 \mathrm{t} / \mathrm{ha} \cdot \mathrm{yr})$ and nitrates $(2 \mathrm{~kg} \mathrm{NO}-\mathrm{N} / \mathrm{ha} \cdot \mathrm{yr})$ (Figure 4 ) because of low soil salinity $(\mathrm{ECa}=0.24 \mathrm{dS} / \mathrm{m})$ and small volumes of applied irrigation $(29 \mathrm{~mm} / \mathrm{yr})$ and nitrogenous fertilizer (5 kg N/ha.yr). Zone B, with only $23 \%$ of irrigated surface, applied small volumes of irrigation (42 mm/yr) and nitrogenous fertilizer ( $25 \mathrm{~kg} \mathrm{~N} / \mathrm{ha} \cdot \mathrm{yr})$, presenting a low export of nitrate $(1 \mathrm{~kg} \mathrm{NO}-\mathrm{N} / \mathrm{ha} \cdot \mathrm{yr})$. However, the higher soil salinity $(\mathrm{ECa}=0.35 \mathrm{dS} / \mathrm{m})$ increased the export of salts to $1.7 \mathrm{t} / \mathrm{ha} \cdot \mathrm{yr}$. Zone $\mathrm{C}$, with $73 \%$ of irrigated surface, presented much higher applied irrigation volumes $(222 \mathrm{~mm} / \mathrm{yr})$ and fertilizer amounts (87 kg N/ha.yr), which conditioned higher export of salts $(2.3 \mathrm{t} /$ ha.yr) and nitrates (24 $\left.\mathrm{kg} \mathrm{NO}_{3}-\mathrm{N} / \mathrm{ha} \cdot \mathrm{yr}\right)$, although presenting low soil salinity $(\mathrm{ECa}=0.17 \mathrm{dS} / \mathrm{m})$. Finally, zone $\mathrm{D}$, which reached an irrigated surface $(72 \%)$ similar to that of zone $C$, presented a lower export of salts $(1.9 \mathrm{t} / \mathrm{ha} \cdot \mathrm{yr})$ and nitrates $(6 \mathrm{~kg}$ $\left.\mathrm{NO}_{3}-\mathrm{N} / \mathrm{ha} \cdot \mathrm{yr}\right)$, even though soil salinity $(\mathrm{ECa}=0.27 \mathrm{dS} / \mathrm{m})$ and nitrogen fertilization ( $99 \mathrm{~kg} \mathrm{~N} / \mathrm{ha} \cdot \mathrm{yr}$ ) were higher than those of zone $\mathrm{C}$. This could be the result of the smaller amount of applied irrigation $(174 \mathrm{~mm} / \mathrm{yr})$ or the possible dilution of water at location $\mathrm{P}_{\mathrm{D}}$ (seepage from supply canal), which was not taken into account in the drainage flow associated with each area.

Temporally, the influences of the implementation of irrigation and climate on the export of pollutants were observed. Under unirrigated conditions (2004 to 2005), the high precipitation in
2004 increased drainage-and thus the export of pollutants. But 2005, with much lower precipitation, presented the lowest export of salts and nitrates for the four zones. During irrigation (2006 to 2008), the four zones evolved differently depending on the percentage of irrigated land. Zones $A$ and $B$ maintained the levels of export as when in unirrigated conditions, with peaks associated with rainfall-which, in the case of salts, were more pronounced in the highest salinity zone (zone B). Conversely, the trend of zones $\mathrm{C}$ and $\mathrm{D}$ indicated that, starting from the minimum unirrigated values in 2005, exports increased with small annual variations in function of the percentage of irrigated land and year. For zone $\mathrm{C}$, the maximum export of salts and nitrates in an irrigated year were, respectively, 37\% and 109\% higher than exports in the rainy year of 2004 .

Multivariate AnalysisThe cluster analysis used to analyze the spatiotemporal dynamics of the export of salts and nitrates in Lerma basin divided the 20 year-zone combinations into three groups (Figure 5). Group I consisted of four year-zone combinations (20\%) corresponding integrally to year 2005. This year was characterized for being the driest $(212 \mathrm{~mm})$, unirrigated, and with no application of nitrogen fertilization (as the basin was uncultivated). This resulted in the lowest drainage flows $(19 \mathrm{~mm})$ as well as the lowest export of salts $(0.7$ t/ha.yr) and nitrates (4 kg NO$-\mathrm{N} / \mathrm{ha} \cdot \mathrm{yr}$ ) (Table 2).

Group II consisted of four other year-zone combinations (20\%), including years (2007 and 2008) and zones (C and D) with higher irrigation $(437 \mathrm{~mm})$, resulting in the highest drainage flow $(78 \mathrm{~mm})$ without having had the greatest amount of rainfall (386 $\mathrm{mm})$. Such a high drainage flow caused by irrigation return flows led to the highest export of salts (2.6 t/ha.yr), even though the soils of this group presented low salinity $(\mathrm{ECa}=0.22 \mathrm{dS} / \mathrm{m})$. The greater percentage of irrigated land led to a greater application of nitrogenous fertilizer (197 kg N/ha.yr), also producing the greatest nitrate export via drainage $\left(21 \mathrm{~kg} \mathrm{NO}_{3}\right.$ $\mathrm{N} /$ ha $\cdot \mathrm{yr}$ ).

Finally, Group III constituted of 12 year-zone combinations (60\%), including all combinations of the heaviest rainfall year (2004) and year-zones least irrigated. Although presenting the highest precipitation $(480 \mathrm{~mm} / \mathrm{yr})$, the scarce irrigation applied (49 $\mathrm{mm} / \mathrm{yr}$ ) resulted in an intermediate flow compared to the other groups $(55 \mathrm{~mm} / \mathrm{yr})$. Nitrogen fertilization was rather low (24 kg N/ha.yr), which provided an export of nitrates $\left(5 \mathrm{~kg} \mathrm{NO}_{3}-\right.$ $\mathrm{N} / \mathrm{ha} \cdot \mathrm{yr}$ ) similar to those of the unirrigated group (Group I). However, the greater soil salinity $(\mathrm{ECa}=0.27 \mathrm{dS} / \mathrm{m})$ and precipitation in this group conditioned an export of salts $(1.5 \mathrm{t} /$ ha.yr) closer to the group with the greater irrigation percentage (Group II).

Correlation analysis (Table 3) examined the relationship between the variables considered in the cluster. Precipitation

Table 2-Number and percentage of year/zone combinations classified in the three groups discriminated by the cluster analysis from precipitation (P), irrigation (I), flow (Q), soil apparent electrical conductivity (ECa), nitrogen fertilization (NF), and salt (S) and nitrate $\left(\mathrm{NO}_{3}-\mathrm{N}\right)$ exports in drainage.

\begin{tabular}{|c|c|c|c|c|c|c|c|c|}
\hline \multirow[b]{2}{*}{ Group } & \multirow[b]{2}{*}{$n^{\circ}(\%)$} & \multicolumn{3}{|c|}{$m m / y r$} & \multirow{2}{*}{$\begin{array}{c}E C a \\
d S / m\end{array}$} & \multirow{2}{*}{$\begin{array}{c}N F \\
k g N / h a \cdot y r\end{array}$} & \multirow{2}{*}{$\begin{array}{c}S \\
t / h a \cdot y r\end{array}$} & \multirow{2}{*}{$\begin{array}{c}\mathrm{NO}_{3}-\mathrm{N} \\
\mathrm{kg} \mathrm{NO}-\mathrm{N} / \mathrm{ha} \cdot \mathrm{yr}\end{array}$} \\
\hline & & $P$ & $I$ & $a$ & & & & \\
\hline I & $4(20)$ & 212 & 0 & 19 & 0.25 & 0 & 0.7 & 4 \\
\hline II & $4(20)$ & 386 & 437 & 78 & 0.22 & 197 & 2.6 & 21 \\
\hline III & $12(60)$ & 480 & 49 & 55 & 0.27 & 24 & 1.5 & 5 \\
\hline
\end{tabular}

Water Environment Research, Volume 84-Copyright (C) 2012 Water Environment Federation Uncorrected Page Proofs 
Table 3-Pearson correlation matrix for irrigation (I), precipitation (P), nitrogen fertilization (NF), soil apparent electrical conductivity $(\mathrm{ECa})$, flow (Q), and salt $(\mathrm{S})$ and nitrate $\left(\mathrm{NO}_{3}-\mathrm{N}\right)$ exports in drainage $(\mathrm{n}=20)$.

\begin{tabular}{|c|c|c|c|c|c|c|}
\hline & $I$ & $P$ & $N F$ & $E C a$ & a & $S$ \\
\hline$N F$ & $0.951^{\star * *}$ & & & & & \\
\hline$a$ & $0.732^{\star \star *}$ & $0.481^{*}$ & $0.716^{\star * \star}$ & & & \\
\hline$S$ & $0.610^{* *}$ & & $0.622^{\star \star}$ & & $0.759^{* * *}$ & \\
\hline $\mathrm{NO}_{3}-\mathrm{N}$ & $0.724^{\star * *}$ & & $0.600^{\star *}$ & $-0.725^{\star \star \star}$ & $0.599^{\star \star \star}$ & $0.608^{* *}$ \\
\hline
\end{tabular}

was only significantly related to drainage flow, whereas irrigation was positively related to the export of pollutants and the drainage flow. Surprisingly, ECa was not significantly related to the export of salts, although was negatively related to the export of nitrates. This is probably because irrigation was planned for soils with low salinity, and therefore more fertilized. In fact, nitrogen fertilization is significantly related to both the export of salts and nitrates, as fertilization is consistently associated with irrigation ( $\mathrm{p}<0.001)$; this, in turn, is associated with the export of salts.

Power et al. (2001), Zotarelli et al. (2007), and Gheysari et al. (2009), in studies developed in the United States and Iran, showed that the export of nitrates from the root zone depends on both the volumes of irrigation and nitrogen fertilization applied, with an increase in exports as a response to the addition of water and/or nitrogen. In Lerma basin, this increase is quite pronounced because the expansion of irrigation has led to increased applications of nitrogenous fertilizers. Thus, in the area with greater volumes of applied irrigation (zone C), $15 \mathrm{~kg}$ $\mathrm{NO}_{3}-\mathrm{N} /$ ha $\cdot \mathrm{yr}$ exported in the early years without irrigation reached $41 \mathrm{~kg} \mathrm{NO}-\mathrm{N} / \mathrm{ha} \cdot \mathrm{yr}$ in the most irrigated year (2008). These values are in the same order as those measured by Casalí et al. (2008) in unirrigated basins with greater pluviometry (16 and $37 \mathrm{~kg} \mathrm{NO}-\mathrm{N} / \mathrm{ha} \cdot \mathrm{yr}$ ) and lower than those registered in traditional flood-irrigation systems (Causapé et al., 2006). Consolidated irrigation areas similar to those of Lerma-in which an efficient management of irrigation and nitrogen fertilization has been carried out-exported between 14 and 49 $\mathrm{kg} \mathrm{NO}$ - N/ha.yr (Cavero et al., 2003). These values are in the same order as those recorded in the area with the greater irrigation percentage in Lerma in the last study year (zones $\mathrm{C}$ and $\mathrm{D}$ ), indicating the need to seek agricultural management alternatives to minimize the export of nitrates.

As an alternative, the utilization of wetlands for nutrient retention in agrarian basins has proven to be highly efficient in environmental scenarios similar to the studied basin (MorenoMateos et al., 2010). These authors found retentions between $40 \%$ and $60 \%$ of the nitrate input, which involved approximately $500 \mathrm{~g} \mathrm{NO}_{3}-\mathrm{N} / \mathrm{m}^{2}$ wetland.yr. As a result of such retention rates, the use of between $1.5 \%$ and $4 \%$ of the basin as wetland was proposed-which, in Lerma basin, means to dedicate between 11 and 30 ha to wetlands distributed throughout the basin. Implementation of this measure should be focused on the most affected zones: C and D.

\section{CONCLUSIONS}

The methodology applied proved to be manageable to assess spatiotemporal impacts of the transition of agrarian basins into irrigated areas, and can be easily used in other countries with important irrigation expansion, such as the United States, China, and Brazil.

The comparative analysis of the different zones of the Lerma basin before, during, and after introduction of irrigation demonstrated the influence of irrigation on water quality. Irrigation generated additional flows that reduced the natural high salinity of the gully and increased nitrate concentration. Although factors such as precipitation and soil salinity are important in influencing concentrations of salts and nitrates, irrigation was found to be the main influence in increasing exports of salts and nitrates. The expansion of irrigated areas generated an increase in drainage flows, which in turn increased leaching of salts and nitrates from the soil. This expansion then also caused an increase in use of nitrogen fertilizers, which ultimately increased the nitrate content available for leaching.

Results suggested that the salinity of the Lerma gully could continue to decline in subsequent years as a result of the gradual leaching of salts from the soil, which ultimately will translate into a decrease in exports of salts. Following the trend observed so far, the complete transition of the basin into the planned irrigated land will increase nitrate concentration in water, as well as the export of nitrates to levels up to those registered in consolidated irrigation lands with similar characteristics.

The combination of preventive measures (improvement in efficiency of agricultural management, mainly irrigation and fertilization) with corrective measures (implementation of wetlands) will be crucial to minimize potential future agroenvironmental impacts.

\section{ACKNOWLEDGMENTS}

The authors wish to thank project PMO19/2006 (Government of Aragón) and project CGL2009-13410-C02-01 (Spanish Ministry of Science and Innovation). Raphael Abrahão was supported by the EU Program of High Level Scholarships for Latin America (Alßan Scholarship No. E07D400318BR).

Submitted for publication , ; accepted for publication , .

\section{References}

Allen, R., Pereira, L., Raes, D., Smith, M. (1998) Crop Evotranspiration. Guidelines for Computing Crop Water Requirements; FAO Irrigation and Drainage Paper 56; Food and Agriculture Organization: Rome, Italy.

Ayers, R.S., Westcot, D.W. (1994) Water Quality for Agriculture; FAO Irrigation and Drainage Paper 29; Food and Agriculture Organization: Rome, Italy.

Baldock, D., Caraveli, H., Dwyer, J., Einschutz, S., Petersen, J.E., SumpsiVinas, J., Varela-Ortega, C. (2000) The Environmental Impacts of Irrigation in the European Union. A report to the Environment Directorate of the European Commission by the Institute for European Environmental Policy, London, in Association with the 
Polytechnical University of Madrid and the University of Athens; Madrid, Spain.

Cai, X. M., McKinney, D. C., Rosegrant, M. W. (2003) Sustainability Analysis for Irrigation Water Management in the Aral Sea Region. Agric. Syst., 76, 1043-1066.

Casalí, J., Gastesi, R., Álvarez-Mozos, J., et al. (2008) Runoff, Erosion, and Water Quality of Agricultural Watersheds in Central Navarre (Spain). Agric. Water Manage., 95, 1111-1128.

Causapé, J., Auqué, L., Gimeno, M. J., Mandado, J., Quílez, D., Aragüés R. (2004) Irrigation Effects on the Salinity of the Arba and Riguel Rivers (Spain): Present Diagnosis and Expected Evolution Using Geochemical Models. Environ. Geol., 45, 703-715.

Causapé, J., Quílez, D., Aragüés, R. (2006) Irrigation Efficiency and Quality of Irrigation Return Flows in the Ebro River Basin: An Overview. Environ. Monit. Assess., 117, 451-461.

Causapé, J. (2008) Agro-environmental Evaluation of Irrigation Land. II: Pollution Induced by Bardenas Irrigation District (Spain). Agric. Water Manage., 96, 188-194.

Cavero, J., Beltrán, A., Aragüés, R. (2003) Nitrate Exported in the Drainage Water of Two Sprinkler Irrigated Watershed. J. Environ. Qual., 32, 916-926.

Charbonneau, R., Kondolf, G. M. (1993) Land Use Change in California, USA: Nonpoint Source Water Quality Impacts. Environ. Manage., $17,453-460$.

Custodio, E., Llamas, M. (1983) Hidrología Subterránea; Ediciones: Omega, Spain. [In spanish]

European Environment Agency (1999) Nutrients in European Ecosystems, Environmental Assessment Report $n^{\circ}$ 4; European Environment Agency: Copenhagen, Denmark.

EU: European Union (1998) Council Directive 98/83/CE of 3 November 1998 Imposed to the Surface Waters Devoted to the Production Of water for Human Consumption; Official Journal L 330 (5/12/1998), $32-54$.

García-Garizábal, I., Causapé, J., Abrahão, R. (2009) Evolution of the Efficiency and Agro-environmental Impact of a Traditional Irrigation Land in the Middle Ebro Valley (2001-2007). Span. J. Agric. Res., 7, 465-473.

Gheysari, M., Mirlatifi, S. M., et al. (2009) Nitrate Leaching in a Silage Maize Field Under Different Irrigation and Nitrogen Fertilizer Rates. Agric. Water Manage., 96, 946-954.

Hair, J., Anderson, R., Tatham, R., Black, W. (1998) Multivariate Data Analysis; Prentice-Hall: Englewood Cliffs, New Jersey.

Isaaks, E., Srivastava, R. M. (1989) An Introduction to Applied Geostatistics; Oxford University: New York, New York.

Klocke, N. L., Watts, D. G., Schneekloth, J. P., Davison, D. R., Todd, R. W., Parkhurst, A. M. (1999) Nitrate Leaching in Irrigated Corn and Soybean in a Semi-arid Climate. Trans. ASAE, 42, 1621-1630.
Kruskal, W. H., Wallis, W. A. (1952) Use of Ranks in One-criterion Variance Analysis. J. Am. Stat. Assoc., 47, 583-621.

Lemly, A. D., Finger, S. E., Nelson, M. K. (1993) Sources and Impacts of Irrigation Drainwater Contaminants in Arid Wetlands. Environ. Toxicol. Chem., 12, 2265-2279.

Lovett, G. M., Burns, D. A., Driscoll, C. T., Jenkins, J. C., Mitchell, M. J., Rustad, L., Shanley, J. B., Likens, G. E., Haeuber, R. (2007) Who Needs Environmental Monitoring? Front. Ecol. Environ., 5, 253260.

Mann, H. B., Whitney, D. R. (1947) On a Test of Whether One of Two Random Variables Is Stochastically Larger than the Other. Ann. Math. Stat., 18, 50-60.

MIMAM (2003) Digital Terrain Model $25 \times 25$ m; Spanish Environment Ministry.

Moreno, F., Cayuela, J. A., Fernández, J. E., Fernández-Boy, E., Murillo, J. M., Cabrera, F. (1996) Water Balance and Nitrate Leaching in an Irrigated Maize Crop in SW Spain. Agric. Water Manage., 32, 7183.

Moreno-Mateos, D., Pedrocchi, C., Comín, F.A. (2010) Effects of Wetland Construction on Water Quality in a Semi-arid Catchment Degraded by Intensive Agricultural Use. Ecol. Eng., 36, 631-639.

Power, J. F., Wiese, R., Flowerday, D. (2001) Managing Farming Systems for Nitrate Control: A Research Review from Management Systems Evaluation Areas. J. Environ. Qual., 30, 1866-1880.

Ribbe, L., Delgado, P., Salgado, E., Flügel, W. A. (2008) Nitrate Pollution of Surface Water Induced by Agricultural Non-point Pollution in the Pocochay Watershed, Chile. Desalination, 226, 13-20.

SIAR (2008) Integrated Service Network on Irrigation Advice (Datos de la red agroclimática del Servicio Integral de Asesoramiento al Regante) http://oficinaregante.aragon.es (accessed February 2011) [In spanish].

Tanji, K.K., Kielen, N.C. (2002) Agricultural Drainage Water Management in Arid and Semi-arid Areas; FAO Irrigation and Drainage Paper 61; Food and Agriculture Organization: Rome, Italy.

Thayalakumaran, T., Bethune, M. G., McMahon, T.A. (2007) Achieving a Salt Balance-Should It Be a Management Objective? Agric. Water Manage., 92, 1-12.

Urdanoz, V., Amezqueta, E., Clavería, I., Ochoa, V., Aragües, R. (2008) Mobile and Georeferenced Electromagnetic Sensors and Applications for Salinity Assessment. Span. J. Agric. Res., 6, 469-478.

U.S. Environmental Protection Agency (2002) National Water Quality Inventory - 2000 Report. U.S. EPA Office of Water; Washington, D.C.

Wahl, T. (2000) Winflume USDA. www.usbr.gov/wrrl/winflume (accessed July 2008).

Zotarelli, L., Scholberg, J. M., Dukes, M. D., Muñoz-Carpena, R. (2007) Monitoring of Nitrate Leaching in Sandy Soils: Comparison of Three Methods. J. Environ. Qual., 36, 953-962. 